\title{
PRIORITIZATION OF SUPPLIER SELECTION CRITERIA IN BATIK INDUSTRY: A FUZZY-AHP APPROACH
}

\author{
Aries Susanty, Diana Puspitasari, Sri Hartini, Ganung Sugi \\ Department of Industrial Engineering \\ Diponegoro University \\ Tembalang, Semarang, Indonesia \\ E-mail: ariessusanty@gmail.com
}

\begin{abstract}
Supplier selection is one of the most important problems in the supply chain of batik industry and its have strong effect on performance of SMEs. Proper selection of suppliers is very important for the profitability of SMEs and the direct and indirect consequences of poor decision making will impact the ability of SMEs to gain competitive advantage. This study reveals the application of Fuzzy AHP in some of SMEs in the batik industry to determine the relative importance of the criteria in supplier selection and to assign the weight to that criteria. These in turn help to identify the preferences of owner of SMEs at Laweyan Center (Solo), Kauman Center (Pekalongan), and Wijirejo Center (Yogyakarta) selecting their suppliers in the context of purchasing fabric and wax. The result of this study shows us that percentage of defect rate and offering price are the top rank and second rank in supplier selection in batik industry. SMEs in Laweyan Center has different patterns in assessing the degree of importance (rank) of the various criteria for supplier selection compared to the other region.
\end{abstract}

Keywords: supplier selection, SMEs, batik industry, Laweyan Centre, Kauman Centre, Wijirejo Cente, Fuzzy AHP

\section{Introduction}

Supplier selection is defined in as the process of finding the suppliers being able to provide the buyer with the right quality products and/or services at the right price, at the right quantities and at the right time (Chamodrakas, et al. 2010). Choosing a supplier with an appropriate criteria is one of the most important stages in the course of supply chain in batik industry and considerably can reduce cost of making batik, causes to competitive advantage and increases the level of customer satisfaction. According to Ghodsypour and O'Brien, 1998, in most industries, the cost of raw materials and component parts constitutes the main cost of a product, such that in some cases it can account for up to $70 \%$. In such circumstances, proper selection of suppliers is very important for the profitability of SMEs and the direct and indirect consequences of poor decision making will impact the ability of SMEs to gain competitive advantage. Batik is "wax writing", a way of decorating cloth by covering a part of it with a coat of wax and then dyeing the cloth. It is a technique of covering the parts of fabric which will not receive the color. The waxed areas keep their original color and when the wax is removed the contrast between the dyed and undyed areas forms the pattern (TREDA 2008). 
There are several solution approaches to the supplier selection problem in the literature, e.g. Hierarchy Process, Fuzzy Analytic Hierarchy Process, Data Envelopment Analysis, Mixed Integer Programming, TOPSIS, Fuzzy TOPSIS, QFD, Fuzzy QFD, Analytic Network Process and Expert Systems (Aktepe and Ersoz, 2011). This study reveals the application of Fuzzy AHP in some of SMEs in the batik industry to determine the relative importance of the criteria and to assign the weight to the criteria. These in turn help to identify the preferences of SMEs in selecting their suppliers in the context of purchasing fabric and wax. The reason why Fuzzy AHP is used in supplier selection decision is that the decision making environment in such a system is so complex. There could be several criteria used by SMEs in its supplier selection decision for purchasing fabric and wax, such as the price offered, part quality, on-time delivery, after-sales services, supplier location and supplier's financial status. Apparently, supplier selection is a multi-criteria problem that includes both quantitative and qualitative factors. It is necessary to make a trade-off between these tangible and intangible factors while considering a suitable supplier. Fuzzy-AHP also used because of some of the criteria are subjective and qualitative in nature, it is very difficult for the decision maker to express the preferences using exact numerical values and to provide exact pairwise comparison judgments.

\section{Literature Review}

Fuzzy Analytic Hierarchy Process embeds the fuzzy theory to basic Analytic Hierarchy Process (AHP), which was developed by Saaty (1980). One of the first fuzzy AHP applications was performed by van Laarhoven and Pedrycz (1983). They defined the triangular membership functions for the pairwise comparisons. Afterwards, Buckley (1985) has contributed to the subject by determining the fuzzy priorities of comparison ratios having triangular membership functions. Chang (1996) also introduced a new method related to the usage of triangular numbers in pairwise comparisons.

Fuzzy set theory implements groupings of data with boundaries that are not sharply defined (i.e. fuzzy). Any methodology or theory implementing "crisp" definitions such as classical set theory, arithmetic, and programming, may be "fuzzified" by generalizing the concept of a crisp set to a fuzzy set with blurred boundaries. The benefit of extending crisp theory and analytical methods with fuzzy techniques is the strength in solving realworld problems, which inevitably entail some degree of imprecision in the variables and parameters measured and processed for the application. A triangular fuzzy number (TFN) is the special class of the fuzzy number whose membership is defined by three real numbers, expressed as $(1, \mathrm{~m}, \mathrm{u})$. The triangular membership function is represented as follows (Okoli and Pawlowski 2004; Chatterjee and Mukherjee 2010). Fig 1. displays the structure of a Triangular Fuzzy Number (TFN) and Table 1 describes a pairwise comparison performed by using Fuzzy linguistic scale and a triangular fuzzy number.

$\mu_{A}=\left\{\begin{array}{l}\frac{x-l}{m-l}, l \leq x \leq m \\ \frac{\mu-x}{\mu-m}, m \leq x \leq \mu \\ 0, \text { otherwise }\end{array}\right.$ 
1.0

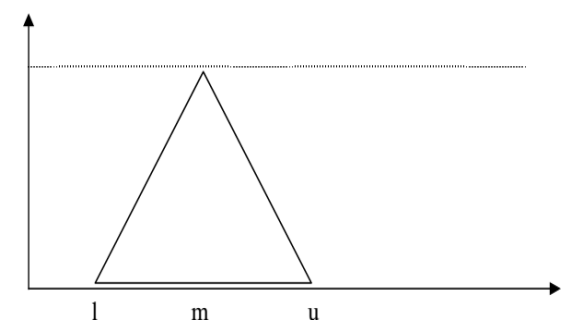

Fig. 1. Two triangular fuzzy numbers M1 and M2

Source: Chatterjee and Mukherjee (2010).
Table 1. Importance (or preference) of one criterion over another

\begin{tabular}{|l|c|}
\hline Linguistic scale & $\begin{array}{l}\text { Triangular fuzzy } \\
\text { numbers }\end{array}$ \\
\hline Absolute & $(7 / 2,4,9 / 2)$ \\
\hline Very strong & $(5 / 2,3,7 / 2)$ \\
\hline Strong & $(3 / 2,2,5 / 2)$ \\
\hline Fairly strong & $(2 / 3,1,3 / 2)$ \\
\hline Equal & $(1,1,1)$ \\
\hline Fairly weak & $(2 / 3,1,3 / 2)$ \\
\hline Weak & $(2 / 7,1 / 2,2 / 3)$ \\
\hline Very weak & $(2 / 9,1 / 4,2 / 7)$ \\
\hline Zero & \\
\hline
\end{tabular}

Source: Gholipour et al (2009)

\section{Hypotheses/Objectives}

The objective of this study is to develop a general model, which will help to solve the supplier selection problems of fabric and wax purchasing in batik industry. More detail, this study aims to:

1. Determine the criteria which are used to select suppliers of fabric and wax in the batik industry

2. Determine the relative importance of the criteria and to assign the weight to the criteria with Fuzzy AHP

3. Determine the difference of level of importance (rank) of each criteria in Laweyan Center (Solo), Kauman Center (Pekalongan), and Wijirejo Center (Yogyakarta),

\section{Research Design/Methodology}

The data used in this study are collected and obtained by filling out the questionnaires and face-to-face interviews. In this phase, filling out the questionnaire and interviews have been conducted by visiting the selected owner of SMEs batik in Laweyan Center (Solo), Kauman Center (Pekalongan), and Wijirejo Center (Yogyakarta). Filling out the questionnaire and interviews aimed at identifying the priorities of the various criteria highlighted in selecting suppliers. The purpose of interviewing is to have a clearer picture on how the supplier selection process is performed and at the same time to clarify any doubts regarding the questionnaires answered by the owner of SMEs. Some criteria and hierarchy models for supplier selection process in the batik industry were identified by the author based on extensive study of some literature and this criteria and interview conducted by an expert.

Based on extensive study of some literature, there are six factors which are considered for determining some criteria for selecting the supplier of fabric and wax, namely quality, price, delivery, and services. From this factor, the author can identify the nine criteria for supplier selection in batik industry

\section{- Quality.}

According to Dickson (1966) and Weber et al (1991), quality is part of the most important factor in supplier selection. It is because the success of the buying organization is highly dependent on how well the suppliers perform. It is also important that the supplier and the buyer have the same idea of what satisfactory 
quality is (Leenders and Fearon, 2010). They need to agree on the basic requirements of the transaction, the way in which the requirements are to be realized, how to check that the requirements are fulfilled and the measures to be taken when the expectations are not met (Weele, 2010). In this study, the quality factor is represented by the percentage of defect parts criteria.

- Price.

Quality in itself is not sufficient to ensure that the suppliers can avoid extra costs while offering the right quality. Purchase price is also a significant factor for the purchasing organization. In 1998, 92\% of buyers responding to a Purchasing Magazine Survey cited that negotiating price as one of their top responsibilities. Nearly as many respondents said price remains a key criterion they use to select a supplier (Kottler \& Keller, 2002). In this study, the price factor is represented by offering price criteria and quantity of discount criteria. Offering price refers to the comparison between the sale price offered by the supplier with a purchase price demanded by the SMEs, whereas, discount price refers to price reductions provided by the supplier after negotiations

\section{- Delivery}

Performance delivery describes the efficiency rate of business operations when preparing and delivering an order to a customer (Gallego, 2011). In this study, delivery factor is represented by short lead time in order fulfillment, on time delivery rate, and flexibility of order fulfillment criteria. Lead time defined as the time it takes from the moment an order is placed until it arrives. In related to performance of suppliers, short lead time refers to the capability of the supplier to deliver the order in the short time since the order is placed. On time delivery rate, referring to the frequency of occurrence of delay in delivery of goods by the supplier; whereas flexibility of order fulfillment refers to the ability of the supplier to respond the changes based on the customer's demand, price structure, order frequency and order volume.

\section{- Service}

Buyers and suppliers of manufactured products appear to agree that service is increasing in importance related to product and price issues. A manufacturer, even the best manufacturer in the world, who can't respond to customers' needs, is not going to survive. The effort by manufacturers to be more customers focused must be matched with buyer expectation; buyer must be ensuring that their suppliers are giving them the level of service that is required and at reasonable cost (Donaldson, 1994). He defined service as all those activities provided by the seller that enhance or augment the product and have value for the buyer, thus increasing customer satisfaction and encouraging patronage and loyalty between the parties. In this study, service factor is represented by ease the warranty claim process, ease of ordering process, and ease of communication. Ease the warranty claim process refers to the extent to which the supplier is able to provide simple procedures that make it easier to return the goods which are not in accordance with the specifications. Ease of ordering process refers to the extent to which the supplier is able to carry out cooperation in the procurement of goods in accordance with simple procedures, whereas ease of communication refers to the extent to which the supplier is able to provide effective communication with the SMEs because suppliers have cultural similarity, same communication language and electronic data interchange capabilities.

International Symposium of 4

the Analytic Hierarchy

4

Washington, D. C.

Process June 29 - July 2, 2014 
All criteria for supplier selection are prioritized and structured in hierarchical models before using Fuzzy AHP. Initially, a hierarchy was developed and submitted to the experts to check whether these descriptions in the model hierarchy were understandable or not. After revising the descriptions of criteria (the definition of the criteria above is the final definition after revision), finally hierarchy models of supplier selection for purchasing fabric and wax were developed (see Fig. 2).

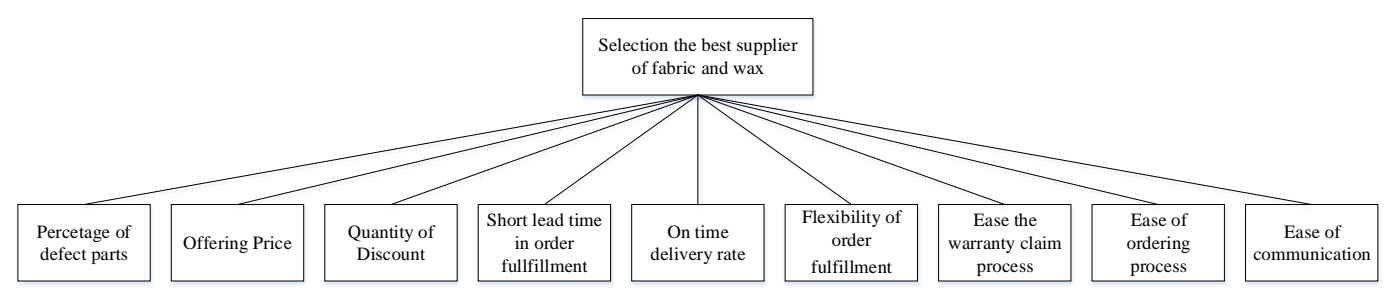

Fig. 2. Hierarchical models of supplier selection for purchasing fabric and wax

\section{Data/Model Analysis}

The importance weight of 1 to 9 criteria for supplier selection in purchasing fabric and wax is shown in Table 2

Table 2. Level of Importance of 1 to 9 criteria for supplier selection in purchasing fabric and wax

\begin{tabular}{|c|c|c|c|c|c|c|c|c|c|}
\hline \multirow[b]{2}{*}{ Criteria } & \multicolumn{3}{|c|}{ Laweyan Center (Solo) } & \multicolumn{3}{|c|}{ Kauman Center (Pekalongan) } & \multicolumn{3}{|c|}{ Wijirejo Center (Yogyakata) } \\
\hline & $\begin{array}{l}\text { Level of } \\
\text { importance }\end{array}$ & Rank & CR & $\begin{array}{l}\text { Level of } \\
\text { importance }\end{array}$ & Rank & CR & $\begin{array}{l}\text { Level of } \\
\text { importance }\end{array}$ & Rank & CR \\
\hline Percentage of defect rate & 0.2114 & 1 & \multirow{9}{*}{$\begin{array}{r}0,076 \\
(<0,1)\end{array}$} & 0.2512 & 1 & \multirow{9}{*}{$\begin{array}{r}0,095 \\
(<0,1)\end{array}$} & 0.2512 & 1 & \multirow{9}{*}{$\begin{array}{r}0,082 \\
(<0,1)\end{array}$} \\
\hline Offering price & 0.2076 & 2 & & 0.1706 & 2 & & 0.2509 & 2 & \\
\hline Quantity of discount & 0.0413 & 8 & & 0.0411 & 9 & & 0.0257 & 9 & \\
\hline $\begin{array}{l}\text { Short lead time in order } \\
\text { fulfillment }\end{array}$ & 0.1111 & 4 & & 0.0984 & 4 & & 0.1141 & 4 & \\
\hline On time delivery & 0.1426 & 3 & & 0.0895 & 5 & & 0.0905 & 5 & \\
\hline $\begin{array}{l}\text { Flexibility of order } \\
\text { fulfillment }\end{array}$ & 0.1024 & 6 & & 0.0627 & 7 & & 0.0439 & 7 & \\
\hline $\begin{array}{l}\text { Ease the warranty claim } \\
\text { process }\end{array}$ & 0.0509 & 7 & & 0.1614 & 3 & & 0.1557 & 3 & \\
\hline Ease of ordering process & 0.1062 & 5 & & 0.0429 & 8 & & 0.0405 & 8 & \\
\hline Ease of communication & 0.0265 & 9 & & 0.0821 & 6 & & 0.0642 & 6 & \\
\hline
\end{tabular}

After calculating the weights of each criteria, the ranking list of criteria shows us that percentage of defect part and offering price criteria occupy the top-rank and second-rank in all surveyed regions (Laweyan Center: 0.2114; Kauman Center: 0.2512; Wijirejo Center: 0.2512). Both of these criteria become an important criteria in supplier selection by SMEs batik in Laweyan, Kauman, and Wijirejo Center because most of SMEs batik is a small industry with a relatively small capital, so they always choose suppliers who offering the lowest price. But price is not the most important criteria. The quality of the fabric and wax is more important than price. It is because the quality of the fabric and wax will influence the quality of finished products. The SMEs batik will suffer more losses if they accept too many defective products.

International Symposium of the Analytic Hierarchy

Process June 29 - July 2, 2014 
The result of calculating weights of each criteria also shows us that SMEs in Laweyan Center has different patterns in assessing the level of importance (rank) of the various criteria for supplier selection compared to SMEs in Kauman and Wijirejo Center. In Laweyan Center, on time delivery is the third criteria, followed by short lead time in order fulfillment, ease or ordering process, flexibility of order fulfillment, ease the warranty claim process, quantity of discount, and ease of communication. In Kauman and Wijirejo, ease of ordering process is the third criteria, followed by short lead time fulfillment, on time delivery, ease of communication, flexibility of order fulfillment, ease of ordering process, and quantity discount. The inconsistency or referred to as CR in all surveyed regions is $<0.10$ reported by the Expert Choice Software. This implies that the group decision makers' (owner of SME) evaluation is consistent.

\section{Limitations}

The limitation of this study is the sample size only on three regions of batik whereas there is so much region which also produce the same batik in Indonesia. In the future, the same study will be extended to a much larger region of batik, so that more representative weights of the relative importance of the criteria may be obtained, for the batik industry scenario.

\section{Conclusions}

This study reveals the application of Fuzzy AHP in some of SMEs in the batik industry to determine the relative importance of the criteria and to assign the weight to the criteria for supplier selection in purchasing fabric and wax. Although there has been a lot of literature which attempts to choose suppliers by using Fuzzy AHP, all such studies are done at the firm level and results could vary across firms even in the same industry, and will vary across industries. All such significant studies attempted to understand the requirements at the firm level and that too often at a product category level by comparing amongst a few suppliers and their capabilities for that product category. Difference with previous study, the findings of this study would be of significance in understanding the priority of supplier selection criteria on the regional level and try to see whether there is a differences prioritization of supplier selection criteria in each region. The result of this study shows us that percentage of defect rate and offering price are the top rank and second rank in supplier selection in batik industry. SMEs in Laweyan Center has different patterns in assessing the degree of importance (rank) of the various criteria for supplier selection compared to SMEs in Kauman and Wijirejo Center.

\section{Acknowledgement}

This work has been funded by the Direktorat Penelitian dan Pengabdian Kepada Masyarakat, Directorate General of Higher Education, Ministry of National Education through grand for "Strategis Nasional Research". The authors wish to acknowledge to Directorate General of Higher Education for giving the author some funds to participate and attend this international symposium. The authors wish to acknowledge to the Rector of Diponegoro University, Dean of Faculty Engineering, and head of the Department of Industrial Engineering for their support. The authors also wish to acknowledge our gratitude and appreciation to all the partners in "Strategis Nasional Research" for their 
IJAHP Article: Mu, Saaty/A Style Guide for Paper Proposals To Be Submitted to the International Symposium of the Analytic Hierarchy Process 2014, Washington D.C., U.S.A.

contribution during the development of various ideas and concepts presented in this paper.

\section{Key References}

Aktepe, A and Ersoz, S. (2011). A fuzzy analytic hierarchy process model for supplier selection and a case study. International Journal of Research and Development, 3 (1), 33-37

Buckley, J. J. (1985). Fuzzy hierarchical analysis. Fuzzy Sets Systems, 17 (1), 233-247.

Chamodrakas, I., Batis, D., Martakos, D. (2010). Supplier selection in electronic marketplaces using satisficing and fuzzy AHP. Expert Systems with Applications, 37 (1), 490-498

Chang, D.-Y. (1996). Applications of the extent analysis method on fuzzy AHP. European Journal of Operational Research, 95(3), 649-655.

Chatterjee, D and Mukherjee, B. (2010). Study of Fuzzy-AHP model to search the criterion in the evaluation of the best technical institutions: a case study. International Journal of Engineering Science and Technology, 2(7), 2010, 2499-2510

Dickson, G. W. (1966). An analysis of vendor selection systems and decisions. Journal of Purchasing, 2 (1), 5-17

Donaldson, B. (1994). Supplier selection criteria on the service dimension: some empirical evidence. European Journal of Purchasing \& Supply Management, 1(4), 209-217

Gallego, L. V. (2011). Review of existing methods, models and tools for supplier evaluation. Unpublished Master Thesis, Department of Management and Engineering, Linköpings Universitet, Sweden

Ghodsypour, S. H. and O'Brien, O. (1998). A decision support system for supplier selection using an integrated analytical hierarchy process and linear programming. International Journal of Production Economic. 56-67 (1), 199-212.

Gholipour, R., Jandaghi, G., Rajaei, R. (2014). Contractor selection in MCDM context using fuzzy AHP. Iranian Journal of Management Studies (IJMS), 7(1), 151-173

Kotler, P. and Keller, K.L. (2006) Marketing Management. Prentice Hall: New Jersey.

Leenders, M. and Fearon, H. (1997). Purchasing \& Supply Management. Irwin: Chicago

Okoli, C. and Pawlowski, S. D. (2004). The Delphi method as a research tool: an example, design considerations and applications. Information \& Management, 42(1), 15-29.

Saaty, T.L. (1980). The Analytic Hierarchy Process. New York, USA: McGraw-Hill

TREDA (Trade Research and Development Agency). (2008) Indonesia Batik- A Cultural Beauty. Jakarta, Indonesia: Ministry of Trade of the Republic of Indonesia

Van Laarhoven, P.J.M., and Pedrycz, W. (1983). A fuzzy extension of Saaty"s priority Theory. Fuzzy Sets and Systems, 11(1-3), 199-227.

Weber, C. A., Current, J. r., Benton, W. C. (1991). Vendor selection criteria and methods. European Journal of Operational Research, 50(1), 2-18

Weele, A. J. van. (2010). Purchasing and Supply Chain Management: Analysis, Strategy, Planning, and Practice. Cengage Learning EMEA: Netherlands 